\begin{tabular}{|c|c|}
\hline & $\begin{array}{c}\text { International Journal of Current Research in } \\
\text { Biosciences and Plant Biology } \\
\text { BXCELLENT } \\
\text { PUBLISHERS }\end{array}$ \\
Volume $4 \bullet$ Number 4 (April-2017) $\bullet$ ISSN: 2349-8080 (Online) \\
Journal homepage: www.ijcrbp.com
\end{tabular}

\title{
Antimicrobial and Phytochemical Properties of Areca catechu L. Leaf and Root Extracts
}

\author{
K. Ambika ${ }^{1 *}$ and B. Rajagopal ${ }^{2}$ \\ ${ }^{I}$ Assistant Professor, Department of Microbiology, Sree Ramakrishna College of Naturopathy and Yogic Sciences, Kulasekaram- \\ 629 161, Tamil Nadu, India \\ ${ }^{2}$ Assistant Professor, Department of Zoology, Government Arts and Science College, Dharmapuri-636 705, Tamil Nadu, India
}

*Corresponding author.

\begin{abstract}
Areca catechu L. is a commonly used herb in Ayurvedic medicine. Areca catechu L. belongs to the family Arecaceae is commonly called as Betel nut, grows in much of the tropical pacific, Asia and parts of East Asia. It is one of the most commonly used drug in the world containing alkaloids, tannins, carbohydrate and protein that have anthelmintic, antibacterial, antifungal, anti-inflammatory and anti oxidant activities. Plants produce a wide variety of phytochemical constituents, which are secondary metabolites and are used either directly or indirectly in the pharmaceutical industry. 'For centuries, man has effectively used various components of plants or their extracts for the treatment of many diseases, including bacterial infections. In the present study acetone extracts of Areca catechu leaf and root were subjected for antimicrobial activity by well-diffusion method against five bacterial strains and five fungal strains. The results revealed that the extracts exhibited strong inhibitory activity against all the tested organisms (zone of inhibition of 3-15 mm). The extracts were screened for their phytochemical constituents by standard protocols' and were shown to contain carbohydrates, proteins, alkaloids, flavonoids, saponins, terpenoid, coumarins and tannins. The antimicrobial activity of these extracts is possibly linked to the presence of flavonoids, saponins and/or tannins.
\end{abstract}

\section{Introduction}

Herbal medicine practice plays an important role in the primary healthcare delivery system in most developing countries. The WHO estimates that $80 \%$ of the population living in rural areas use or depend on herbal medicine for their health needs (WHO Traditional Medicine Strategy, 2002). Herbal medicines are defined as any preparation containing one or more active herbal substances or herbal extractives. For majority of these preparations, the active principles or compounds are unknown. Among the first priorities designed by WHO in its strategy for Traditional Medicine, the study of plants for external use with antiseptic and wound healing promoting activity are emphasized (Akerele, 1984). Many medicines including strychnine, aspirin, vincristine, and taxol are of herbal or plant origin. About one quarter of the present prescription drugs dispensed by community pharmacies in the United States contain at least one active principle originally derived from plant 
materials (Farmsworth and Morris, 1976). The increasing use or overuse of antibiotics in the treatment of bacterial infections is bringing on an increase in pathogenic organisms that are resistant to available antibiotics. Consequently, it is necessary to increase administered doses, combine antibiotics or provide new antibiotics with lesser tendency for pathogenic organisms to develop resistance to.

An antimicrobial is a substance that kills or inhibits the growth of microbes such as bacteria, fungi or viruses. Antimicrobial substances include not just antibiotic, but synthetically formed as well. Antimicrobial property is the ability of substances produced or present, to inhibit the pathogen. Spices are the product of herbaceous plant which has been used for about centuries to enhance the flavor and aroma of food (Bassetti et al., 2002). In recent years antimicrobial properties of medicinal plants are being increasingly reported from different parts of the world.

The use of phytochemicals as natural antimicrobial agents commonly called "biocides" is gaining popularity. There is growing interest in correlating phytochemical constitutions of plant with its pharmacological activity. Phytochemical analysis has identified more than 100 alkaloids (Gilani et al., 2006). The plant extracts are plant derived compounds which are likely to provide a valuable source of new medicinal agents (Harborne, 1992). The phytochemical investigations revealed that the plant contains various groups of natural compounds; triterpenes, benzoquinones, flavonoids and steroids $(\mathrm{Li}$ and McLauggghlin, 1989).

Areca catechu L. (Palmae, Arecaceae) commonly known as Betel palm or Betel nut tree is a species of palm. Areca palms are growing in India, Malaysia, Taiwan and many other Asian countries for their economically important seed crop. It is a medium-sized tree growing to $20 \mathrm{~m}$ tall with a trunk $20-30 \mathrm{~cm}$ in diameter. The leaves are 1.5-2 $\mathrm{m}$ long, pinnate with numerous crowded leaflets (Jaiswal et al., 2011). Areca nut palm is cultivated primarily for its kernel obtained from the fruit, which is chewing in its tender, ripe or processed form. Uses for areca nut other than chewing are negligible. Its export prospects are also very much limited. That is most of the people are not know its medicinal properties. Powdered nuts are prescribing in diarrhoea and urinary disorders (Anonymous, 1985). Extensive studies on the medicinal properties and chemical constituents of Areca fruit especially the nut is there. Nevertheless, studies on root are scarce. Areca catechu root is using in the traditional medicines of Kerala against various ailments like urinary tract disorders, skin irritations, worm disturbances and as a component in health tonic preparation (Baby and Regi Raphael, 2014) and young leaf sheath is used in the treatment of migraine (Baby and Regi Raphael, 2013). According to (Baby and Regi Raphael, 2014) Areca root crude extract showed prominent antimicrobial, anthelmintic and antioxidant properties.

Areca nut tree (Areca catechu) is referred to as betel nut tree; which is a species of palm tree that grows in tropical humid regions like Asia Pacific and parts of east Africa The nuts, husks, young shoots, buds, leaves and roots of Areca catechu are used in various medicinal preparations (Staples and Bevacqua, 2006). In this consequence, the present study was carried out in Areca catechu leaf and root by which the plant extract have been collected and analysed. The analysis involves antimicrobial activity and phytochemical analysis.

\section{Materials and methods}

\section{Plant material}

Areca catechu leaf and root were collected from Perunchani in Kanyakumari District, Tamilnadu, India for the proposed study. The collected plants were identified by morphological characters.

\section{Preparation of plant extract}

The collected fresh leaf and root were rinsed with distilled water and air dried in shade. The dried plant material was homogenized by electric mixer grinder to obtain coarse powder and stored in air-tight bottles for further analysis. The shade dried, powdered were extracted separately (Mukherjee, 2002) with Acetone solvents by hot extraction method using Soxhlet apparatus. The extracts were evaporated in a rotary vacuum evaporator at $40^{\circ} \mathrm{C}$ to dryness and stored at $4^{\circ} \mathrm{C}$ in an air tight bottle for further analysis (Ragavendra et al., 2011).

\section{Antimicrobial activity of acetone extract of Areca catechu leaf and root}

Antimicrobial activity of acetone extracts of leaf and root of Areca catechu were carried out by disc diffusion method (Bauer et al., 1966; Murrey et al., 1995). 


\section{Culture media and inoculum}

The media used for antibacterial test was Nutrient agar and for antifungal test was Potato dextrose agar. The bacteria were inoculated into nutrient broth and incubated at $37^{\circ} \mathrm{C}$ for $4 \mathrm{hrs}$. Similar procedure was done for fungal strains by inoculating in Potato dextrose broth for $6 \mathrm{hrs}$.

\section{Microorganisms used}

The microorganisms used for antimicrobial studies were obtained from Microbial Type Culture Collection (MTCC), Chandigarh. The different bacterial strains (Gram positive and Gram negative) used are .Bacillus subtilis (MTCC 121), Enterobacter aerogenes (MTCC 111), Klebsiella pneumoniae (MTCC 4030), Staphylococcus epidermidis (MTCC 6810) and Enterococcus faecalis (MTCC 439). The different fungal strains used for study were Candida glabrata (MTCC 3984), Candida albicans (MTCC 183), Candida tropicalis (MTCC 184), Aspergillus fumigatus (MTCC 4354) and Aspergillus niger (MTCC 961).

\section{Antimicrobial activity}

Antimicrobial activity of acetone extracts of leaf and root were determined by disc diffusion method. Briefly, Petri plates containing $20 \mathrm{ml}$ of nutrient agar (for bacteria) potato dextrose agar (PDA) medium (for fungi) were allowed to dry in sterile chamber. The sterile filter paper discs (Whatman No.1 paper, $5 \mathrm{~mm}$ diameter) were impregnated with $10 \mu \mathrm{g}$ of acetone extracts was placed on the inoculated agar surface. Acetone solvent was placed as negative control. The plates were incubated at $37^{\circ} \mathrm{C}$ for $24 \mathrm{hrs}$ for antibacterial activity. The inoculated plates were incubated for $48-72 \mathrm{hrs}$ at $28^{\circ} \mathrm{C}$ for antifungal activity. The antimicrobial activity against each test organism was quantified by determining the zone of inhibition around the paper discs in millimeters. Each assay was replicated three times and results expressed as the mean of three replicates. All results were expressed as Mean \pm Standard Deviation (SD) of three replicates.

\section{Phytochemical analysis}

\section{Tests for tannins}

Ferric chloride test: To 2-3 ml of extract, few drops of ferric chloride solution was added. Formation of bluegreen colour indicates the presence of tannin.

\section{Test for saponins}

Froth formation test: $1 \mathrm{ml}$ of the extract was diluted with $20 \mathrm{ml}$ of distilled water and was shaken in a graduated cylinder for 15 minutes. The formation of 1 $\mathrm{cm}$ layer of foam indicates the presence of saponins.

\section{Test for terpenoids}

Crude extract was dissolved in $2 \mathrm{ml}$ of chloroform and evaporated to dryness. To this, $2 \mathrm{ml}$ of concentrated $\mathrm{H}_{2} \mathrm{SO}_{4}$ was added and heated for about 2 minutes. A grayish colour indicates the presence of terpenoids.

\section{Tests for flavonoids}

Ferric chloride test: To 2-3 ml of extract, few drops of ferric chloride solution were added. Blue-green colour precipitate indicates the presence of flavonoids

\section{Tests for protein and amino acid}

a) Biuret test: To $3 \mathrm{ml}$ of extract, $4 \% \mathrm{NaOH}$ and few drops of $1 \% \mathrm{CuSO}_{4}$ solution were added and observed for violet or pink colour.

b) Ninhydrin test: To $3 \mathrm{ml}$ of extract, 3 drops of $5 \%$ ninhydrin solution was added and heated in boiling water bath for 10 minutes and observed for purple or bluish colour.

\section{Test for alkaloids}

$2-3 \mathrm{ml}$ of the extract was added with few drops of Dragendroffs reagent and then orange brown precipitate formed was noted.

\section{Test for carbohydrate}

Fehling's test: An equal volume of Fehling's A (copper sulphate in distilled water) and Fehling's B (potassium tartrate and sodium hydroxide in distilled water) reagents were mixed along with few drops of extract solution and boiled. A brick precipitate of cuprous oxide was formed if reducing sugars are present.

\section{Test for coumarins}

To the test sample, $10 \% \mathrm{NaOH}$ and chloroform were added. Formation of yellow colour indicates the presence of coumarins. 


\section{Results and discussion}

\section{Antimicrobial activity of acetone extracts of leaf and root of Areca catechu}

The antimicrobial activity of acetone extracts of leaf and root of Areca catechu were investigated by agar disc diffusion method. The used parts of the plant showed antimicrobial activity against bacterial and fungal strains in varying proportions (Tables 1-4).

The compounds that are responsible for therapeutic effects are usually the secondary metabolites. The extracts were subjected to systematic phytochemical screening for the presence of chemical constituents such as carbohydrates by Benedict's test, proteins by Biuret test, alkaloids by Wagner' reagent test, flavonoids by ferric chloride test, saponins by foam test, steroids by Leibermann-Burchards test and tannins by ferric chloride test (Kokate, 1993; Hosamani et al., 2011).

In acetone leaf extract, the maximum zone of inhibition of extract was found to be $15.67 \pm 1.53 \mathrm{~mm}$ against
Enterococcus faecalis. The minimum zone of inhibition of the acetone leaf extract was $11.33 \pm 2.31 \mathrm{~mm}$ against Bacillus subtilis (Table 1). In acetone root extract, the highest zone of inhibition was exhibited against Enterobacter aerogenes $(13.33 \pm 4.93 \mathrm{~mm})$, while the lowest inhibitory activity was observed against Enterococcus faecalis $(08.33 \pm 0.58 \mathrm{~mm})$. A positive control (Gentamycin) showed the zone of inhibition ranging from $19.6 \pm 0.57 \mathrm{~mm}$ to $28.6 \pm 1.15 \mathrm{~mm}$, whereas negative control showed no activity against the tested bacteria (Table 2).

In acetone leaf extract of Areca catechu, the maximum zone of inhibition was found to be $14.33 \pm 3.21 \mathrm{~mm}$ against Aspergillus niger. The lowest zone of inhibition of acetone leaf extract was observed against Candida glabrata $(3.00 \pm 5.20 \mathrm{~mm}$ ) (Table 3).

Acetone root extract showed the highest zone of inhibition against Candida albicans $(14.00 \pm 4.58 \mathrm{~mm})$, while the lowest inhibitory activity was observed against Aspergillus fumigatus and Candida tropicalis $9.33 \pm 0.58$ $\mathrm{mm}$ (Table 4).

Table 1. Antibacterial activity of acetone extracts of Areca catechu leaf.

\begin{tabular}{llll}
\hline \multirow{2}{*}{ S1. No. } & \multirow{2}{*}{ Bacterial Pathogens } & Zone of inhibition $\mathbf{~ m m}$ mean \pm SD & \\
\cline { 3 - 4 } & & Leaf extract & Gentamycin $(\mathbf{5 0 m c g} / \mathbf{d i s c})$ \\
\hline 1 & Klebsiella pneumoniae & $13.00 \pm 1.00$ & $22.6 \pm 1.12$ \\
2 & Staphylococcus epidermidis & $12.33 \pm 1.15$ & $18.6 \pm 0.68$ \\
3 & Bacillus subtilis & $11.33 \pm 2.31$ & $21.5 \pm 0.5$ \\
4 & Enterococcus faecalis & $15.67 \pm 1.53$ & $18 \pm 1.09$ \\
5 & Enterobacter aerogenes & $12.67 \pm 1.15$ & $20.1 \pm 0.86$ \\
\hline
\end{tabular}

Table 2. Antibacterial activity of acetone extracts of Areca catechu root.

\begin{tabular}{llll}
\hline \multirow{2}{*}{ SI. No } & \multirow{2}{*}{ Bacterial Pathogens } & \multicolumn{2}{l}{ Zone of inhibition $\mathbf{~ m m}$ mean \pm SD } \\
\cline { 3 - 4 } & & root extract & Gentamycin $(\mathbf{5 0 m c g} / \mathbf{d i s c})$ \\
\hline 1 & Klebsiella pneumoniae & $12.33 \pm 1.15$ & $28.6 \pm 1.15$ \\
2 & Staphylococcus epidermidis & $10.67 \pm 2.52$ & $22.6 \pm 0.57$ \\
3 & Bacillus subtilis & $10.33 \pm 2.08$ & $21.5 \pm 0.5$ \\
4 & Enterococcus faecalis & $8.33 \pm 0.58$ & $22.8 \pm 1.04$ \\
5 & Enterobacter aerogenes & $13.33 \pm 4.93$ & $19.6 \pm 0.57$ \\
\hline
\end{tabular}

Table 3. Antifungal activity of acetone extracts of Areca catechu leaf.

\begin{tabular}{llll}
\hline \multirow{2}{*}{ S1. No } & \multirow{2}{*}{ Fungal Pathogens } & Zone of inhibition $\mathbf{~ m m}$ mean $\mathbf{\pm S D}$ & \\
\cline { 3 - 4 } & & Leaf extract & Nystatin $(\mathbf{1 0 \mu g} / \mathbf{d i s c})$ \\
\hline 1 & Aspergillus fumigatus & $13.33 \pm 3.06$ & $14.5 \pm 0.5$ \\
2 & Aspergillus niger & $14.33 \pm 3.21$ & $8.3 \pm 0.57$ \\
3 & Candida albicans & $11.67 \pm 1.15$ & $14.3 \pm 1.15$ \\
4 & Candida glabrata & $3.00 \pm 5.20$ & $9.5 \pm 0.5$ \\
5 & Candida tropicalis & $7.67 \pm 6.66$ & $17.1 \pm 0.76$ \\
\hline
\end{tabular}


Table 4. Antifungal activity of acetone extracts of Areca catechu root.

\begin{tabular}{|c|c|c|c|}
\hline \multirow{2}{*}{ Sl. No } & \multirow{2}{*}{ Fungal Pathogens } & \multicolumn{2}{|c|}{ Zone of inhibition mm ( mean \pm SD) } \\
\hline & & root extract & Nystatin $(10 \mu \mathrm{g} /$ disc $)$ \\
\hline 1 & Aspergillus fumigatus & $9.33 \pm 0.58$ & $14.5 \pm 0.5$ \\
\hline 2 & Aspergillus niger & $12.33 \pm 0.58$ & $8.3 \pm 0.57$ \\
\hline 3 & Candida albicans & $14.00 \pm 4.58$ & $14.3 \pm 1.15$ \\
\hline 4 & Candida glabrata & $13.33 \pm 2.08$ & $9.5 \pm 0.5$ \\
\hline 5 & Candida tropicalis & $9.33 \pm 1.53$ & $17.1 \pm 0.76$ \\
\hline
\end{tabular}

\section{Phytochemical analysis of Areca catechu leaf extract}

The leaf extract of Areca catechu showed the presence of phytochemical constituents such as saponins and tannins. The acetone root extract showed the presence of phytochemical constituents such as alkaloids, saponins, carbohydrate, tannin, terpenoids and sterol (Table 5).

Table 5. Phytochemical analysis of Areca catechu leaf and root extracts.

\begin{tabular}{lll}
\hline Test & Leaf extract & Root extract \\
\hline Alkaloids & - & + \\
Amino acids & - & - \\
Coumarins & - & - \\
Flavonoids & - & - \\
Saponins & + & + \\
Carbohydrate & - & + \\
Tannins & + & + \\
Terpenoids & - & + \\
Sterol & - & + \\
\hline
\end{tabular}

\section{Conclusion}

Phytochemical screening shows the presence of valuable secondary metabolites, so there is no doubt about that this traditional medicinal plant will give clues for the preparation of new drugs. Past some years, there has been a lot of interest in the investigation of natural materials as sources of new antibacterial agents. Many reports show the effectiveness of traditional herbs against microorganisms as a result, plants are one of the basis for modern medicine to attain new principles. The present study reveals the existence of antimicrobial substances in Areca catechu and further studies are required to find out the active components of medicinal properties in this valuable plant.

\section{Conflict of interest statement}

Authors declare that they have no conflict of interest.

\section{References}

Akerele, O., 1984. WHO's traditional medicine programme: Progress and perspective. WHO Chron. 38, 78-81.

Anonymous, 1985. The Wealth of India (Raw Material). Vol. 1A. Publication and Information Directorate, CSIR, New Delhi.

Baby, A. A., Regi Raphael, K., 2013. An ethno-medical survey on Peechi village of Thrichur district, Kerala, India to unravel the world of traditional ttamoolis. Plant Arch. J. 13(2), 767-769.

Baby, A. A., Regi Raphael, K., 2014. Potential antimicrobial, anthelmintic and antioxidant properties of Areca catechu L. root. Int. J. Pharm. Pharmaceut. Sci. 6(6), 486- 489.

Bassetti, M., Dembry, L. M., Farrel, P. A., Callan, D. A., Andriole, V. T., 2002. Antimicrobial activities of BMS-284756 compared with those of fluoroquinolones and $\beta$-lactams against Grampositive clinical isolates. Antimicrob. Agents Chemother. 46(1), 234-238.

Bauer, A. W., Kirby, W. M., Sherris, J. C., Turck, M., 1966. Antibiotic susceptibility testing by a standardized single disc method. Am. J. Clin. Pathol. 45, 493-496.

Farmsworth, N. R., Morris, R. W., 1976. Higher plants The sleeping giant of drug development. Am. J. Pharm.147, 46.

Gilani, S. A., Kikuchi, A., Shinwari, Z.K., Khattak, Z.I., Watanab, K. N., 2006. Phytochrmical, pharmacological and ethnobotanical studies of Rhazya stricta Decne. Phytother. Res. 21, 301-307.

Harborne, J.B., 1992. Phytochemical Methods. Chapman and Hall Publications, London. pp.7-8.

Hosamani, P. A., Lakshman, H. C., Sandeepkumar, K., Hosamani, R.C., 2011. Antimicrobial activity of leaf extract of Andrographis paniculata Wall. Sci. Res. Rep. 1, 92-95.

Jaiswal, P., Kumar, P., Singh, V.K., Singh, D.K., 2011. Areca catechu L. A valuable herbal medicine 
against different health problems. Res. J. Med. Plant. 5, 145-152.

Kokate, C. K., 1993. Practical Pharmacognosy. $4^{\text {th }}$ Edn. Vallabh Prakashan, New Delhi. pp.107-111, 178181.

Li, X. H., McLauggghlin, J. O., 1989. Bioactive compounds from the roots of Myrsine africana. J. Nat. Prod. 52, 660-662.

Mukherjee, P.K., 2002. Quality Control of Herbal Drugs: Approaches to Evaluation of Botanicals. $1^{\text {st }}$ Edn. Business Horizons, New Delhi. pp.390-403.

Murrey, P. R., Baron, E.J., Pfaller, M.A., Tenover, F.C.,
Yolke, R.H., 1995. Manual of Clinical Microbiology, $6^{\text {th }}$ Edn. ASM, Washington DC.

Ragavendra, B.S., Prathibha, K.P., Vijayan, V.A., Larvicidal efficacy of Eugenia jambolana Linn. J. Entomol. 8(5), 491-496.

Staples, G.W., Bevacqua, R.F., 2006. Areca catechu (betel nut palm), ver.1.3. In: Species Profiles for Pacific Island Agroforestry (Ed.: Elevitch, C.R.). Permanent Agriculture Resources (PAR), Holualoa Hawai'i. pp.1-17.

WHO, 2002. Traditional Medicines Strategy, WHO/EDM/TRM/200.1, 2002-2005.

\section{How to cite this article:}

Ambika, K., Rajagopal, B., 2017. Antimicrobial and phytochemical properties of Areca catechu L. leaf and root extracts. Int. J. Curr. Res. Biosci. Plant Biol. 4(4), 107-112. doi: https://doi.org/10.20546/ijcrbp.2017.404.016 